\title{
MEMOTIVASI BELAJAR SISWA MELALUI MODEL PEMBELAJARAN COOPERATIVE TIPE SCRIPT PADA MATERI SPLDV DI KELAS VIII SEMESTER I SMP NEGERI 3 KUBU
}

\author{
Cahye \\ SMP Negeri $3 \mathrm{Kubu}$ \\ E-mail: cahye3@gmail.com
}

\begin{abstract}
This research background was by low motivation to learn mathematics in the classroom. This classroom action research is aimed to improve the motivation to learn mathematics of VIII grade SMP Negeri 3 Kubu. Classroom action research done in two cycles with 30 students. Techniques of collecting data is observation by researchers and collaborators. The data was analyzed qualitatively with the data source from the observer. The success of the model Cooperative script in declared successful, less successful or unsuccessful. Motivation indicators defined by the researchers themselves with $\geq 60 \%$ of students motivated. Indicators of motivation in this research there are four, namely: 1). Responsible, $100 \%$ 2). Challenges, 70\%, 3). Inovatif, 63\%, 4). Competitive, $80 \%$. Thereby motivating student learning using Cooperative learning model type of script can improve mathematics learning in the classroom.
\end{abstract}

Keywords: Student motivation, learning models Cooperative script.

Pendidikan merupakan salah satu aspek yang sangat penting dalam kehidupan manusia. Namun kualitas pendidikan di Indonesia sampai saat ini masih belum menggembirakan, khususnya dalam bidang matematika. Siswa hanya dapat mengerjakan soalsoal matematika berdasarkan apa yang di contohkan guru, jika diberikan soal yang berbeda mereka akan mengalami kesulitan dalam menyelesaikannya.

Berdasarkan survei yang dilakukan, banyak guru ketika masuk ke dalam kelas pada awal pelajaran akan menanyakan siapa yang tidak mengerjakan PR. Jika ada siswa yang tidak mengerjakan PR, siswa akan di minta untuk mengerjakan PR nya di luar kelas dan guru akan melanjutkan menjelaskan materi pelajaran berikutnya tanpa membahas PR yang diberikan sebelumnya. Dengan begitu kerja keras yang dilakukan dan menyita banyak waktu pada saat mengerjakan PR dirasakan siswa sebagai penyiksaan. Siswa merasa tidak dihargai. Situasi demikian membuat siswa tidak bersemangat sewaktu mengerjakan PR dan menimbulkan keengganan dalam mengerjakan tugas selanjutnya. Hal-hal 
seperti ini tentu saja sangat tidak baik untuk jiwa dan sisi psikologis siswa. Bisa jadi karena asumsi dan praktek yang keliru dalam memperlakukan PR, tujuan-tujuan pendidikan yang hendak di capai dapat terabaikan begitu saja. Dan juga pendidikan di Indonesia kebanyakan hanya ditekankan pada hafalan dan mencari satu jawaban yang benar terhadap soal-soal yang di berikan. Oleh karena itu tidak heran bila dalam suatu proses pembelajaran tidak ditemukan seorangpun siswa yang mampu mengemukakan ide-ide baru selain yang dijelaskan oleh guru di depan kelas. Hal ini disebabkan karena siswa hanya pasif mengikuti pelajaran di sekolah saja, mereka tidak dilatih mengembangkan daya pikir mereka untuk menjadi aktif dan inovatif sehingga motivasi belajar siswapun berkurang.

Dari keterangan tersebut di atas ada keinginan peneliti untuk mencoba dan mempraktekkan agar kegiatan belajar mengajar menjadi lebih baik dari sebelumnya. Peneliti memotivasi siswa menggunakan model pembelajaran Cooperatif tipe script yaitu salah satu model pembelajaran yang dapat meningkatkan daya ingat siswa. Memotivasi siswa melalui model pembelajaran kooperatif tipe script, salah satu model pembelajaran yang dapat di nilai sebagai suatu hal yang sangat penting dalam kehidupan pendidikan terutama dalam meningkatkan pembelajaran matematika di sekolah. Menurut Slavin (2008: 143) Script merupakan salah satu model pembelajaran kooperatif yang paling baik dan sederhana yang memperhatikan pentingnya kolaborasi (kerja sama) antar sesama siswa dalam belajar berkelompok.

Berdasarkan latar belakang yang telah dipaparkan, peneliti tertarik untuk melakukan penelitian dengan judul “ memotivasi belajar siswa melalui model pembelajaran kooperatif tipe Script pada materi SPLDV di kelas VIII SMP.N. 3 Kubu." Motivasi adalah dorongan dasar yang menggerakkan seseorang dalam bertingkah laku. Menurut Sumadi Suryabrata (2005: 70) Motivasi adalah keadaan yang terdapat pada diri seseorang yang mendorongnya untuk melakukan aktivitas tertentu guna mencapai tujuan. Dengan begitu motivasi adalah kekuatan yang menjadi pendorong untuk individu melakukan sesuatu kegiatan dalam mencapai tujuan. Motivasi mempunyai peranan yang strategis dalam aktivitas belajar seseorang. Jika tidak ada motivasi, maka berarti tidak ada kegiatan belajar. Motivasi belajar merupakan sesuatu kekuatan yang mampu menggerakkan atau mendorong siswa untuk berpartisipasi dalam proses pembelajaran sehingga dapat menguasai materi pelajaran yang sedang diikutinya (Abdorrakhman Ginting, 2008: 86).

Menurut Bistari (2015: 49) bahwa motivasi belajar adalah dorongan dalam diri siswa untuk melakukan aktivitas pembelajaran akibat dari faktor internal maupun faktor eksternal dalam upaya mencapai tujuan pembelajaran. Faktor internal yang ada pada diri siswa dapat berubah menjadi lebih buruk, bila faktor eksternal tidak memberikan efek yang kondusif. Namun, sedikit faktor 
internal yang baik dapat menjadikan lebih maksimal bila tingkah laku dalam pembelajaran yang diharapkan oleh siswa tersebut.

Model pembelajaran adalah pendekatan spesifik dalam mengajar yang memiliki ciri khusus yang tidak dimiliki oleh strategi dan metode. Menurut Trianto (2007: 1), Model pembelajaran adalah suatu perencanaan atau suatu pola yang digunakan sebagai pedoman dalam merencanakan pembelajaran dikelas atau pembelajaran dalam penelitian. Cooperative script merupakan model pembelajaran yang dapat meningkatkan daya ingat siswa (Slavin 1995: 175). Hal tersebut sangat membantu siswa dalam mengembangkan serta mengaitkan fakta-fakta dan konsep-konsep yang pernah didapatkan dalam pemecahan masalah. Pembelajaran cooperative script merupakan salah satu bentuk atau model pembelajaran kooperatif. Hadi (2007; 18) menyatakan bahwa model pembelajaran Cooperative Script adalah secara tidak langsung terdapat kontrak belajar antara guru dengan siswa dan

\section{METODE}

Penelitian ini merupakan penelitian tindakan kelas (PTK) yaitu penelitian yang dilakukan oleh peneliti dikelas atau disekolah tempat peneliti mengajar dengan penekanan pada penyempurnaan atau peningkatan proses dan praktek pembelajaran. Dalam penelitian ini terdiri dari dua siklus. Setiap tahapan siklus terdiri dari perencanaan tindakan, pelaksanaan tindakan, pengamatan tindakan dan refleksi terhadap tindakan. Hasil refleksi siklus I digunakan untuk siswa dengan siswa mengenai cara berkolaborasi. Siswa bersama dengan pasangannya memecahkan masalah secara bersama-sama. Siswa dituntut untuk beraktivitas sendiri, siswa menemukan sendiri suatu konsep atau mampu memecahkan masalah sendiri. Berdasarkan masalah tersebut, dalam pembelajaran Cooperatve Script terjadi suatu kesepakatan untuk berkolaborasi memecahkan suatu masalah dengan sendiri.

Pada pembelajaran Cooperative Script masalah yang dipecahkan bersama akan disimpulkan bersama. Peran guru sebagai fasilitator yang mengarahkan siswa untuk mencapai tujuan belajar. Selain itu, guru mengontrol siswa selama pembelajaran berlangsung dan guru memberi pengarahan jika siswa merasa kesulitan. Pada interaksi siswa selama pembelajaran berlangsung terjadi kesepakatan, diskusi, menyampaikan pendapat dari ide-ide pokok materi, saling mengingatkan dari kesalahan konsep yang disimpulkan, kemudian membuat kesimpulan bersama.

perbaikan rencana tindakan pada siklus berikutnya.

Penelitian ini dilaksanakan di kelas VIII SMP.N.3 Kubu tahun ajaran 2016/2017. Jumlah siswa yang mengikuti kegiatan ini sebanyak 30 siswa yang terdiri dari 13 siswa wanita dan 17 siswa laki-laki. Peneliti dalam penelitian ini bertindak sebagai perencana, penganalisa, dan pengajar serta pengamat dibantu oleh satu orang guru sebagai observer yang bertugas mencatat nama siswa yang termotivasi dalam proses kegiatan belajar mengajar 
pada materi SPLDV menggunakan model pembelajaran Cooperative script.

Alat pengumpul data yang digunakan dalam penelitian ini adalah lembar Observasi siswa yang dilakukan oleh observer selama melakukan pengamatan dalam proses belajar mengajar. Observasi merupakan pengamatan (pengambilan data) untuk mencatat seberapa jauh efek tindakan yang telah mencapai sasaran. Dalam hal ini lembar observasi yang digunakan adalah untuk mengetahui motivasi kegiatan siswa saat proses pembelajaran.

Dalam penelitian tindakan kelas ini, indikator motivasi belajar yang peneliti jadikan rujukan untuk membuat lembar observasi belajar siswa pada Tabel 1.

Tabel 1. Indikator dan ciri-ciri motivasi belajar.

\begin{tabular}{cl}
\hline $\begin{array}{c}\text { Indikator } \\
\text { Motivasi Belajar }\end{array}$ & \multicolumn{1}{c}{ Ciri-Ciri Motivasi Belajar } \\
\hline $\begin{array}{c}\text { Bertanggung } \\
\text { jawab }\end{array}$ & $\begin{array}{l}\text { Aktif mengikuti kegiatan dalam proses pembelajaran di } \\
\text { kelas; seperti memperhatikan peneliti saat menjelaskan, mau } \\
\text { menjawab pertanyaan, dapat menpertahankan pendapat atau } \\
\text { yakin, merespon apa yang dijelaskan peneliti }\end{array}$ \\
\hline \multirow{2}{*}{ Suka tantangan } & $\begin{array}{l}\text { Tertarik/menunjukkan minat pada mata pelajaran yang } \\
\text { diajarkan; seperti ulet menghadapi kesulitan, senang } \\
\text { menerima pelajaran, bekerja dgn tekun tidak mudah putus } \\
\text { asa. }\end{array}$ \\
\hline \multirow{2}{*}{ Inovatif } & $\begin{array}{l}\text { Senang mencari dan memecahkan masalah; seperti memiliki } \\
\text { jawaban alternatif, senang mencari dan tidak bosan dengan } \\
\text { tugas yang diberikan. }\end{array}$ \\
\hline \multirow{2}{*}{ Kompetitif } & $\begin{array}{l}\text { Berperan dengan baik saat tergabung dalam satu kelompok } \\
\text { kelas,seperti semangat dalam kelompok/ perlombaan. }\end{array}$ \\
\hline
\end{tabular}

Sekurang-kurangnya $60 \%$ siswa secara keseluruhan rata-rata persentase, termotivasi selama kegiatan belajar mengajar dikategorikan cukup aktif. Sebelum melaksanakan penelitian, peneliti bersama kolaborator perlu melakukan persiapan agar semua komponen yang direncanakan dapat dikelola dengan baik. Susilo (2009: 2021) menyatakan kegiatan perencanaan mencakup: (1) identifikasi masalah, (2) analisis penyebab adanya masalah, dan (3) pemecahan masalah. Setelah peneliti menemukan masalah, perlu segera melakukan langkah identifikasi penyebab munculnya masalah. Kegiatan selanjutnya adalah melakukan analisis terhadap penyebab adanya masalah yang akan dijadikan landasan berpikir untuk mencari alternatif suatu tindakan yang dapat dikembangkan sebagai bentuk solusi atau pemecahan masalah.

Kegiatan pada tahap ini, peneliti merencanakan: 1)Membuat rencana pelaksanaan pembelajaran 
(RPP) dengan materi SPLDV yaitu menyebutkan pengertian sistem persamaan linier dua variabel, menyelesaikan sistem persamaan linier dua variabel, penerapan SPLDV dalam kehidupan sehari-hari. 2)Membuat lembar observasi untuk siswa. 3)Menunjuk salah satu observer dari teman sejawat untuk mengamati berlangsungnya penelitian/ tindakan. 4)Menentukan waktu atau jadwal pelaksanaan PTK.

Pelaksanaan tindakan Siklus I dan Siklus II dilakukan berdasarkan langkah-langkah yang terdapat dalam pembelajaran model kooperatif tipe script, yaitu pada pelaksanaan RPP meliputi: 1) tahap pendahuluan: a) mengucapkan salam dan berdoa, b) mempersiapkan siswa untuk belajar, c) menginformasikan materi yang akan dibahas, d) melakukan apersepsi dengan melakukan tanya jawab. e) menyampaikan tujuan pembelajaran, f) memotivasi siswa dengan manfaat mempelajari materi SPLDV. 2)Tahap kegiatan inti: a) peneliti membagi siswa untuk berpasangan. b) peneliti memberitahukan materi untuk dibaca dan membuat ringkasan. c) peneliti dan siswa menetapkan siapa yang pertama berperan sebagai pembicara dan siapa yang berperan sebagai pendengar. d) pembicara membacakan ringkasannya untuk prosedur pemecahan masalah selengkap mungkin dengan memasukkan ide-ide pokok dalam ringkasan dan pemecahan masalahnya, sementara pendengar: 1. Menyimak/ mengoreksi/ melengkapi ide-ide yang kurang lengkap. 2. Membantu mengingat / menghafal ideide pokok. e) bertukar peran, semula berperan sebagai pembicara ditukar menjadi pendengar dan sebaliknya,k emudian lakukan seperti kegiatan tersebut kembali. f) merumuskan kesimpulan bersama-sama siswa dan peneliti. g) penutup.

Pengamatan terhadap kegiatan siswa dalam mengikuti proses pembelajaran dalam diskusi kelompok/ berpasangan diamati menggunakan lembar observasi yang sudah peneliti siapkan dan diamati oleh observer sebagai penilai pada tiap siklus. Berdasarkan hasil refleksi peneliti dapat melakukan revisi atau perbaikan terhadap rencana awal guna memasuki rencana siklus berikutnya. Rancangan alur yang digunakan dalam penelitian ini dapat dilihat pada Gambar 1 .

\section{HASIL DAN PEMBAHASAN}

\section{Siklus I}

a. Pertemuan pertama siklus I

1) perencanaan tindakan siklus I

Pada tahap ini, observer bersama peneliti mempersiapkan rencana pelaksanaan pembelajaran (RPP) siklus I yang terdiri dari dua kali pertemuan. Pada pertemuan pertama, peneliti menyiapkan materi yang akan dipelajari tentang pengertian persamaan linier dua variabel dan sistem persamaan linier dua variabel serta contohnya dan penyelesaiannya dengan metode grafik, menyiapkan RPP siklus I yang divalidasi oleh kepala sekolah, menyusun lembar observasi terhadap belajar siswa, membuat lembar catatan lapangan untuk siswa, menyiapkan pembentukan 
kelompok siswa secara berpasangan serta observer dari teman sejawat untuk mengamati berlangsungnya sedangkan lembar observasi peneliti tentang motivasi belajar siswa divalidasi oleh observer.

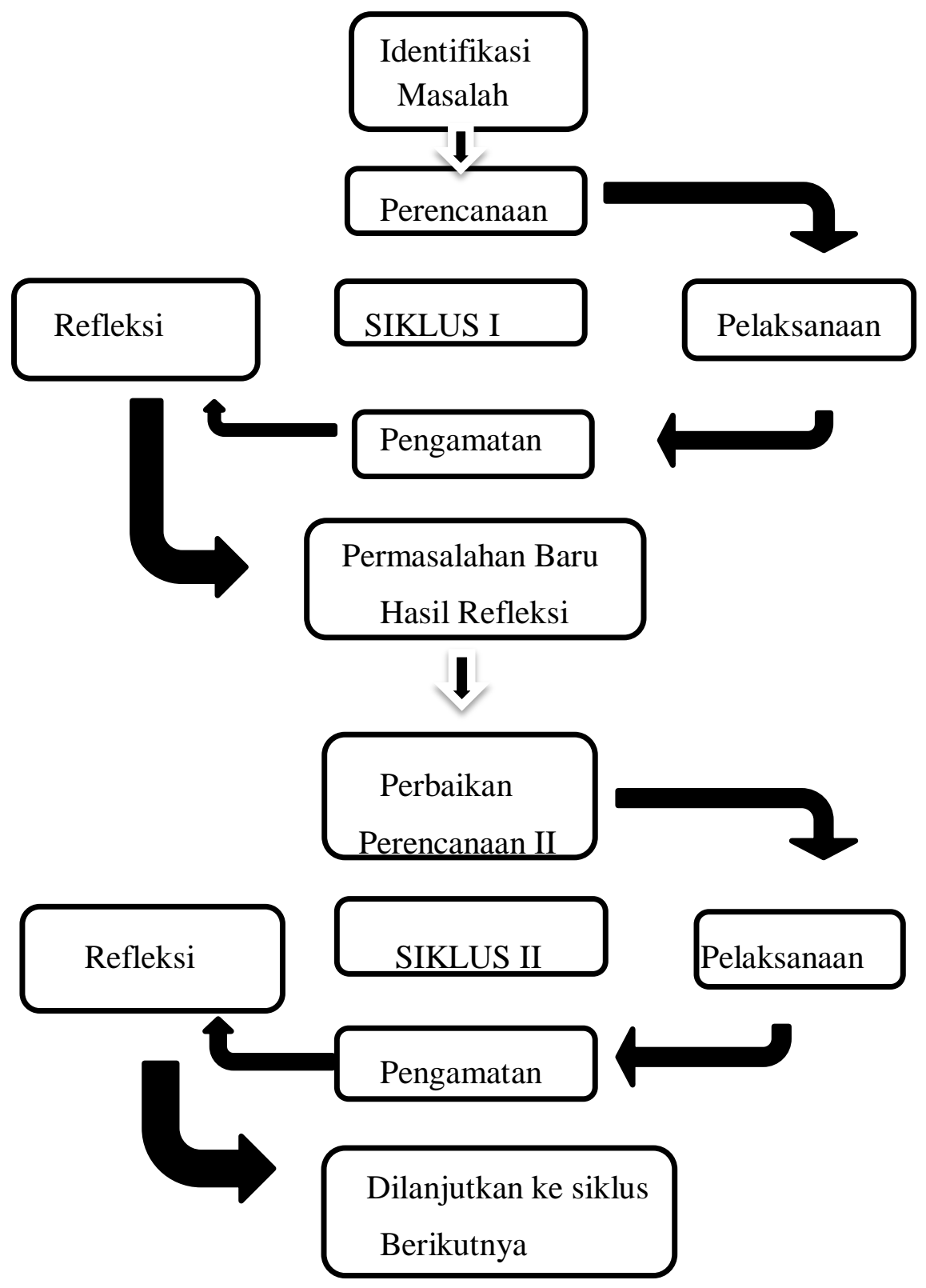

Gambar 1. Model siklus penelitian tindakan kelas (PTK). 
2) Pelaksanaan tindakan siklus I.

Siklus I pada hari selasa, tanggal 1 November 2016 jam 10.00-11.45. Pertemuan kedua hari sabtu tanggal 5 November 2016 pada jam yang sama. Adapun tujuan pembelajaran yang ingin dicapai pada pertemuan pertama adalah: a) memahami persamaan linier dua variabel, b) memahami sistem persamaan linier dua variabel, c) mengenal bentuk umum PLDV, d) dapat menyelesaikan sistem persamaan linier dua variabel dengan metode grafik e) menuliskan pengertian dari sistem persamaan linier dua variabel.Sebelum pembelajaran dimulai observer menempati posisi untuk melakukan pengamatan dan mempersiapkan lembar observasi yang sudah peneliti persiapkan yang akan digunakan pada pengamatan. Pembelajaran dimulai, peneliti menyajikan pembelajaran sesuai dengan RPP pertemuan pertama dan pertemuan kedua. Dalam pelaksanaan proses pembelajaran di kelas observer mengamati kegiatan siswa sekaligus mengamati kesesuaian tindakan. Observer terus mengamati dengan menggunakan lembar observasi selama 2 jam pelajaran (90 menit).

Pada pertemuan pertama peneliti menyajikan materi ke depan kelas dengan menuliskan judul materi yang akan dibahas. Operator yang sudah di tunjuk untuk membantu jalannya penelitian ini mencari posisi yang mudah untuk melihat siswa-siswa yang termotivasi dalam mengikuti kegiatan belajar dengan lembar observasi yang sudah disiapkan oleh peneliti. Skenario tindakan pada siklus I pertemuan pertama dilakukan berdasarkan langkah-langkah yang terdapat dalam pembelajaran model kooperatif tipe script.

3) hasil observasi

Kegiatan belajar siswa yang tampak dikelas selama proses pembelajaran berlangsung diamati menggunakan lembar observasi aktifitas siswa disertai catatan lapangan. Observasi terhadap motivasi belajar siswa dilakukan oleh observer dari guru IPS yang telah ditunjuk oleh kepala sekolah. Adapun hasil observasi motivasi siswa siklus I pertemuan pertama yang dilakukan oleh observer menggunakan lembar observasi yang peneliti siapkan dapat dilihat pada Tabel 2.

Data motivasi belajar siswa bertanggung jawab atau aktif mengikuti kegiatan dalam proses pembelajaran di kelas ada 28 orang siswa dari 30 orang siswa yang ikut atau $93 \%$ cukup aktip atau termotivasi dalam mengikuti pelajaran ini. Ada dua orang siswa dari 30 siswa yang ikut itu tidak banyak berbuat ,suka berjalan, ganggu temannya, kalau tidak maka siswa tersebut pergi keluar alasan ke wc. Siswa 
yang tertarik/berminat terhadap mata pelajaran yang diajarkan ada 10 siswa atau $33 \%$ saja, siswa yang lain menumpukkan kerjanya pada siswa atau pasangannya.
Dan siswa yang suka mencari dan memecahkan masalah 10 orang siswa atau 33\%, siswa yang baik saat bergabung dengan kelompoknya 16 siswa atau 53\%.

Tabel 2. Penyajian data motivasi belajar siswa siklus I pertemuan pertama.

\begin{tabular}{cllcc}
\hline No & $\begin{array}{l}\text { Indikator } \\
\text { motivasi }\end{array}$ & \multicolumn{1}{c}{ Ciri-ciri } & $\begin{array}{c}\text { Jumlah } \\
\text { Siswa } \\
\text { aktif }\end{array}$ & $\begin{array}{c}\text { Persentase } \\
\text { motivasi }\end{array}$ \\
\hline 1 & $\begin{array}{l}\text { Bertanggung } \\
\text { jawab }\end{array}$ & $\begin{array}{l}\text { Aktif mengikuti kegiatan } \\
\text { dalam proses pembelajaran } \\
\text { di kelas; }\end{array}$ & 28 & $93 \%$ \\
\hline 2 & $\begin{array}{l}\text { Suka } \\
\text { tantangan }\end{array}$ & $\begin{array}{l}\text { Tertarik/menunjukkan } \\
\text { minat pada mata pelajaran } \\
\text { yang diajarkan; }\end{array}$ & $33 \%$ \\
\hline 3 & Inovatif & $\begin{array}{l}\text { Senang mencari dan } \\
\text { memecahkan masalah; }\end{array}$ & 10 & $33 \%$ \\
\hline 4 & Kompetitif & $\begin{array}{l}\text { Berperan dengan baik saat } \\
\text { tergabung dalam satu } \\
\text { kelompok kelas }\end{array}$ & 16 & $53 \%$ \\
\hline
\end{tabular}

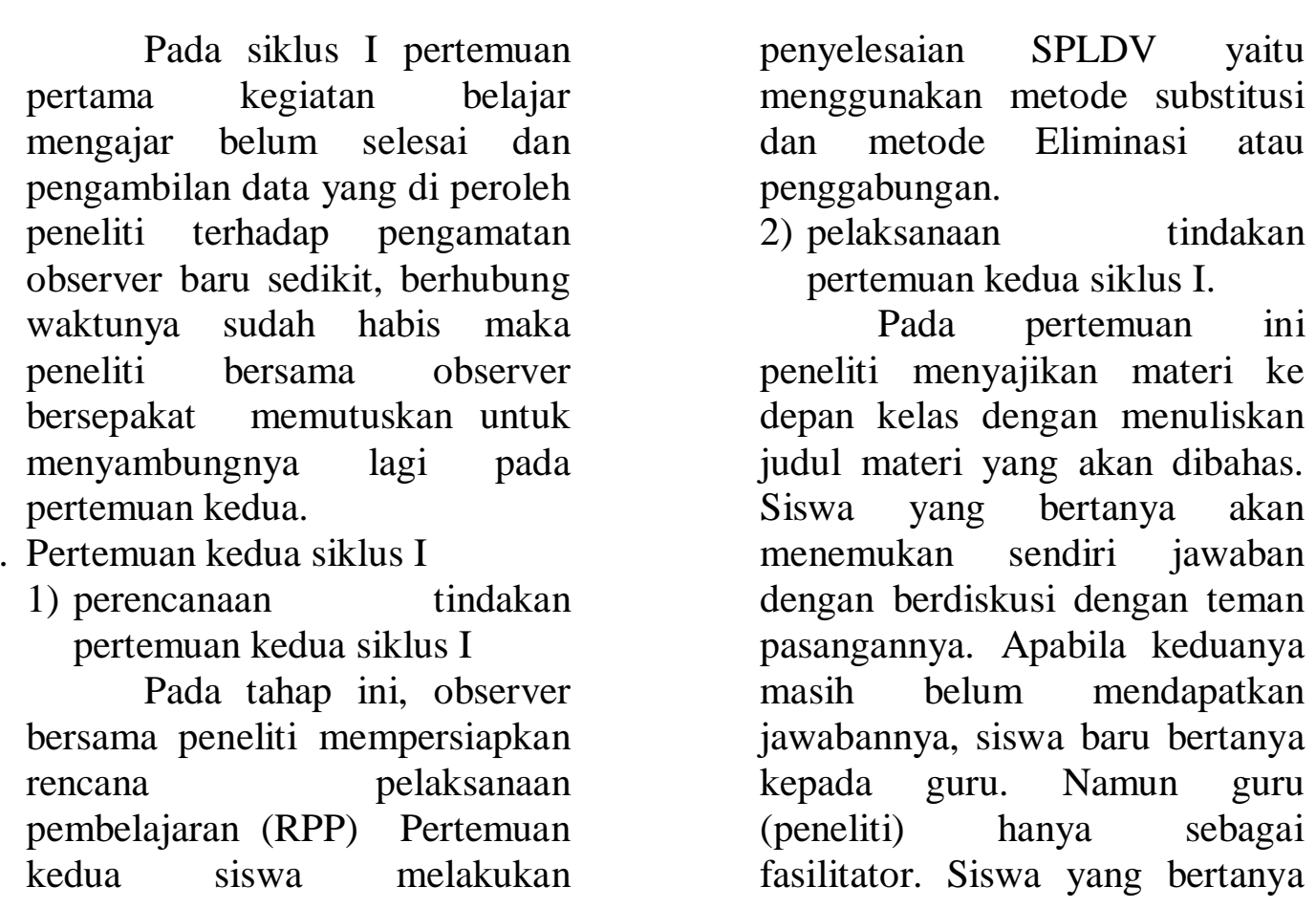


akan diberi arahan oleh peneliti untuk menemukan jawaban dari pertanyaan siswa itu sendiriSeperti yang dikatakan oleh Nurul Iva Andriani dkk (2013:6) bahwa penerapan model pembelajaran Cooperative Script akan membiasakan siswa mengasah ketrampilan berpikir kritisnya sehingga dimungkinkan akan mengimplikasikan ketrampilan berpikir kritis pada kehidupannya akan lebih produktif dan lebih mampu dalam menyelesaikan persoalan yang dihadapinya dengan cerdas dan tepat yang akan menjadikan manusia yang unggul dan siap menghadapi kehidupan yang penuh kompetisi. Operator mencari posisi yang mudah untuk melihat siswa-siswa yang termotivasi dalam mengikuti kegiatan belajar dengan lembar observasi..

3) hasil observasi

Dari pelaksanaan siklus I pertemuan kedua ini diperoleh data hasil observasi tindakan peneliti, yaitu data hasil observasi observer terhadap motivasi belajar siswa menggunakan pembelajaran model cooperative tipe script pada siklus I pertemuan kedua pada hari sabtu tanggal 5 Nopember 2016 jam 10.00-11.45 yaitu dapat dilihat pada Tabel 3.

Tabel 3. Penyajian data motivasi belajar siswa siklus I pertemuan kedua.

\begin{tabular}{|c|c|c|c|c|}
\hline No & $\begin{array}{l}\text { Indikator } \\
\text { motivasi }\end{array}$ & Ciri-ciri & $\begin{array}{l}\text { Jumlah } \\
\text { Siswa } \\
\text { aktif }\end{array}$ & $\begin{array}{l}\text { Persentase } \\
\text { motivasi }\end{array}$ \\
\hline 1 & $\begin{array}{l}\text { Bertanggung } \\
\text { jawab }\end{array}$ & $\begin{array}{l}\text { Aktif mengikuti kegiatan } \\
\text { dalam proses pembelajaran di } \\
\text { kelas; }\end{array}$ & 28 & $93 \%$ \\
\hline 2 & $\begin{array}{l}\text { Suka } \\
\text { tantangan }\end{array}$ & $\begin{array}{l}\text { Tertarik/menunjukkan minat } \\
\text { pada mata pelajaran yang } \\
\text { diajarkan; }\end{array}$ & 18 & $60 \%$ \\
\hline 3 & Inovatif & $\begin{array}{l}\text { Senang mencari dan } \\
\text { memecahkan masalah; }\end{array}$ & 14 & $47 \%$ \\
\hline 4 & Kompetitif & $\begin{array}{ll}\text { Berperan dengan baik } & \text { saat } \\
\text { tergabung dalam } & \text { satu } \\
\text { kelompok kelas } & \end{array}$ & 24 & $80 \%$ \\
\hline
\end{tabular}

Data motivasi siswa yang dapat peneliti lihat dari dalam Tabel 3 ini menunjukkan bahwa pada pertemuan kedua siklus I kegiatan belajar siswa mengalami peningkatan yang sangat baik sekali. Hanya pada indikator inovatif siswa masih rendah yaitu hanya $47 \%$, ini menunjukkan bahwa salah satu yang menjadi 
rujukan dalam pembelajaran yang dilakukan di kelas belum mencapai peningkatan yang signifikan yang peneliti harapkan.

4) Refleksi

Berdasarkan hasil observasi motivasi siswa yang berlangsung dikelas, karena masih ada poin tertentu yang belum mengalami peningkatan maka penelitian ini dikatakan belum berhasil. Cara kerja siswa dalam melakukan tugas berpasangan dalam memecahkan masalah menjadi perhatian yang perlu diperbaiki pada pertemuan berikutnya. Untuk itu peneliti membantu siswa untuk lebih melatih kemampuan berpikir dan berkolaborasi dengan pasangannya untuk menemukan jawaban dari masalah yang ditanyakan siswa, kemudian peneliti bersama observer memutuskan untuk melakukan penelitian selanjutnya. Pada siklus II ini peneliti berupaya agar siswa bersungguh-sungguh melakukan pembelajaran model cooperative tipe script dengan pasangannya.

2. Siklus II

a. Pertemuan pertama siklus II

1) perencanaan tindakan

Pada tahap ini, peneliti dan observer menyusun (RPP), mempelajari materi tentang penerapan SPLDV dalam kehidupan sehari-hari yang dilaksanakan pada hari selasa tanggal 21 Nopember 2016 jam 10.00-11.45. Adapun tujuan pembelajaran yang ingin dicapai adalah: 1). Membuat model matematika dari masalah yang berkaitan dengan sistem persamaan linier dua variabel.

Sebelum pembelajaran dimulai observer menempati posisi untuk melakukan pengamatan dan mempersiapkan lembar observasi yang akan dilaksanakan dan akan digunakan pada saat pengamatan. Observer terus mengamati dengan menggunakan lembar observasi yang sudah dipersiapkan oleh peneliti. Skenario tindakan siklus II dilakukan berdasarkan langkah-langkah yang terdapat dalam pembelajaran model kooperatif script.

2) hasil observasi

Pelaksanaan siklus II diperoleh data hasil observasi tindakan peneliti, yaitu data hasil observasi motivasi siswa pada Tabel 4.

Tabel 4 menunjukkan bahwa kegiatan belajar mengalami peningkatan yang sangat baik sekali dan mencapai kriteria yang diharapkan peneliti yaitu $60 \%$ dianggap siswa sudah termotivasi. Pada indikator inovatif siswa sudah mengalami kenaikan dari $47 \%$ menjadi $63 \%$, ini menunjukkan bahwa pembelajaran yang dilakukan siswa di kelas secara berpasangan mengalami kemajuan. 
Tabel 4. Penyajian data motivasi belajar siswa siklus II.

\begin{tabular}{cllcc}
\hline No & $\begin{array}{c}\text { Indikator } \\
\text { motivasi }\end{array}$ & \multicolumn{1}{c}{ Ciri-ciri } & $\begin{array}{c}\text { Jumlah } \\
\text { Siswa } \\
\text { aktif }\end{array}$ & $\begin{array}{c}\text { Persentase } \\
\text { motivasi }\end{array}$ \\
\hline 1 & $\begin{array}{l}\text { Bertanggung } \\
\text { jawab }\end{array}$ & $\begin{array}{l}\text { Aktif mengikuti kegiatan } \\
\text { dalam proses pembelajaran } \\
\text { di kelas; }\end{array}$ & 30 & $100 \%$ \\
\hline 2 & $\begin{array}{l}\text { Suka } \\
\text { tantangan }\end{array}$ & $\begin{array}{l}\text { Tertarik/menunjukkan } \\
\text { minat pada mata pelajaran } \\
\text { yang diajarkan; }\end{array}$ & 21 & $70 \%$ \\
\hline 3 & Inovatif & $\begin{array}{l}\text { Senang mencari dan } \\
\text { memecahkan masalah; }\end{array}$ & 19 & $63 \%$ \\
\hline 4 & Kompetitif & $\begin{array}{l}\text { Berperan dengan baik saat } \\
\text { tergabung dalam satu } \\
\text { kelompok kelas }\end{array}$ & 24 & $80 \%$ \\
\hline
\end{tabular}

Kebiasaan negatif yang dilakukan siswa masih bisa peneliti upayakan untuk meyakinkan agar tujuan belajar yang ingin diwujudkan menjadi suatu kebutuhan bagi setiap siswa oleh karena itu hasil belajar yang baik adalah suatu kebutuhan guna mencapai sukses yang dicita-citakan. Seperti yang dikemukakan oleh Djamarah (2006: 148) mengemukakan bahwa hanya dengan motivasilah siswa dapat tergerak hatinya untuk belajar bersama temantemannya yang lain.

3) refleksi

Berdasarkan hasil observasi terhadap motivasi siswa, terlihat bahwa tindakan peneliti sudah maksimal yang berdampak pada meningkatnya motivasi belajar siswa. Selain itu kendala-kendala yang dialami pada siklus I dapat diatasi pada siklus II, dimana peneliti sudah memberikan langkah-langkah yang terdapat dalam rencana pembelajaran dan jumlah siswa yang termotivasi secara klasikal telah memenuhi indikator keberhasilan yang diinginkan peneliti. Melihat adanya peningkatan-peningkatan tersebut, maka peneliti bersama observer memutuskan untuk mengakhiri penelitian hingga siklus II saja. 
Motivasi belajar siswa melalui model cooperative tipe script dari siklus I dan siklus II, dapat terlihat pada Gambar 2. Gambar 2 menunjukkan bahwa konsentrasi belajar siswa tidak mudah untuk diketahui oleh peneliti begitu sepintas mata memandang. Hal ini disebabkan terkadang apa yang terlihat melalui aktifitas seorang siswa belum tentu sejalan dengan apa yang sesungguhnya sedang siswa tersebut pikirkan. Sebagai contoh, ketika dihadapan siswa terdapat sebuah buku yang sedang terbuka, dan terlihat sepintas siswa sedang mengamati atau membaca buku tersebut. Akan tetapi benarkah siswa tersebut sedang memusatkan perhatian (berkonsentrasi) terhadap isi buku yang terbuka dihadapannya? Tentu perlu diperiksa, diteliti dan dipahami untuk dapat menyimpulkannya. Sama juga dengan apa yang peneliti lakukan, ketika peneliti menjelaskan pelajaran di depan kelas, dan sepintas terlihat siswa-siswa di kelas tersebut memperhatikan apa yang dijelaskan oleh peneliti. Dapatkah peneliti menjamin bahwa semua siswa sedang konsentrasi terhadap pelajaran yang sedang dijelaskan. Bagaimana jika yang terjadi tidak seperti yang diduga, karena ternyata separuh siswanya hanya diam, akan tetapi tidak berkonsentrasi dengan pelajaran yang sedang disajikan.

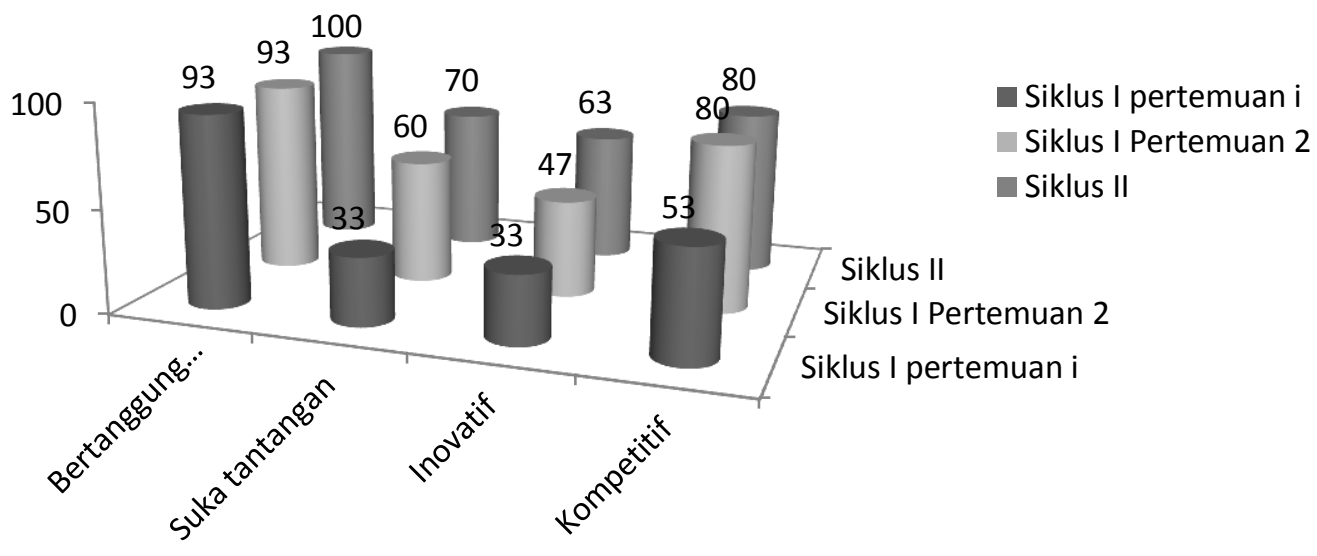

Gambar 2. Motivasi siswa pada siklus I dan siklus II.

Bentuk kegiatan yang peneliti jadikan untuk menciptakan tantangan dalam kegiatan belajar yaitu: merancang dan mengelola kegiatan, memberikan tugas-tugas pemecahan masalah kepada siswa, mendorong siswa untuk membuat kesimpulan pada setiap sesi pembelajaran, mengembangkan bahan pembelajaran yang menarik, membimbing siswa menemukan hasil. Walaupun kemampuan memotivasi diri menjadi sesuatu yang sangat penting sebagai wujud dari kemandirian siswa, namun dalam hal belajar siswa masih memerlukan peran orang lain dalam hal 
ini adalah peneliti untuk memfasilitasi peningkatan motivasi belajarnya. Oleh sebab itu proses pembelajaran yang berdaya dan berhasil guna bukan merupakan kegiatan yang berdiri sendiri, akan tetapi terkait dengan faktor yang bersumber dari kemampuan pengajar (guru) untuk memahami cara berpikir siswa dalam memecahkan permasalahan dari tugas yang diberikan.

Abdillah

(2008), mengemukakan bahwa sebagai pembimbing dalam proses belajar mengajar, seorang guru juga diharapkan mampu; 1)Memberikan informasi yang diperlukan dalam proses belajar, 2)Membantu setiap siswa dalam mengatasi setiap masalah pribadi yang dihadapinya, 3)Mengevaluasi hasil setiap langkah kegiatan yang telah dilakukannya, 4)Memberikan setiap kesempatan yang memadai agar setiap siswa dapat belajar sesuai dengan karakteristik pribadinya, 5)Mengenal dan memahami setiap siswa secara individu maupun secara kelompok. Seperti apa yang dikemukakan oleh Abdillah ini adalah merupakan upaya peneliti untuk mengatasi kesulitan belajar agar proses belajar dalam memecahkan masalah atau persoalan dan senang dalam menyelesaikan tugas menjadikan semangat atau motivasi bagi siswa. Kerja sama yang baik dan ikhlas akan menemukan hasil yang baik dan memuaskan.

\section{SIMPULAN DAN SARAN}

Model pembelajaran Cooperative Script untuk setiap siklus dengan indikator motivasi yaitu siswa yang bertanggung jawab, suka tantangan, Inovatif dan Kompetitif dapat membuat siswa lebih aktif berpartisipasi dalam proses belajar mengajar dan mendapatkan pengalaman belajar yang baru sehingga akan berpengaruh pada peningkatan motivasi belajar siswa. Hal ini terbukti bahwa rata-rata motivasi belajar siswa mencapai $87,5 \%$ dari indikator keberhasilan yaitu $60 \%$ yang ditetapkan. Dengan begitu bahwa penggunaan model pembelajaran Cooperative Script pada siswa kelas VIII pada materi SPLDV semester I SMPN 3 Kubu dapat meningkatkan motivasi belajar siswa.

\section{DAFTAR PUSTAKA}

Abdorrakhman Ginting. (2008). Esensi praktis: Belajar dan Pembelajaran. Bandung: Humaniora.

Abdillh, Husni. (2008). Strategi Bimbingan Belajar Bagi Siswa di Sekolah Dasar. Retrieved Januari 2, 2017, from http://husniabdillah,multiply.com/ journal/item/9/.

Bistari, (2015). Mewujudkan Penelitian Tindakan Kelas. Pontianak: Ekadaya Multi Inovasi.

Djamarah, S. B., \& Aswan, Z. (2006). Strategi Belajar Mengajar. Jakarta: Asdi Mahasatya.

Hadi, S. (2007). Pengaruh pembekalan Model Cooperative Script Terhadap Ketrampilan Berpikir Kritis, Ketrampilan Metakognitif, 
14 Jurnal Pendidikan Matematika dan IPA Vol. 9 No. 1 Januari 2018: 1-14

dan Hasil Belajar Biologi Pada Siswa Laboratorium UM (Makalah Disajikan Pada Seminar Tesis), Malang. Jurnal Pendidikan. Retrieved Desember 2, 2016, from http://jurnal online.um.ac.id.

Andriani, N. I., dkk. (2013). Pengaruh Penerapan Model Pembelajaran Cooperative Script Terhadap Kemampuan Berpikir Kritis dan Hasil Belajar Siswa Kelas XI SMA Di Kota Malang. Retrieved Januari 2, 2017.

Ruseffendi. (1991). Pengantar Kepada Membantu Guru Mengembangkan Kompetensinya Dalam Pengajaran Matematika Untuk Meningkatkan CBSA. Bandung: Tarsito
Slavin. (1995). Cooperative Learning: Theory, Research and Practice Second Edition: Allyn and Bacom Publishers.

Suryabrata, S. (2005). Metodologi Penelitian. Yogyakarta: Rajawali Pers.

Susilo. (2009). Penelitian Tindakan Kelas. Yogyakarta: Pustaka Book Publisher.

Trianto. (2007). Model-model Pembelajaran Inovatif Berorientasi Kontruktivistik. Jakarta: Gramedia Prestasi Pustaka. 